\title{
Vargas Llosa and the Poetics of Power
}

\author{
Alonso Cueto ${ }^{1}$
}

This essay analyzes the importance of a certain type of character that appears in almost all the novels or short stories of Mario Vargas Llosa, namely the leader. We are talking about an essential figure of Vargas Llosa's narrative, a character that controls and defines both the fictional reality of the Peruvian author's great novels, and the Latin American contemporary scene. From his first writings to the most recent ones, Mario Vargas Llosa has explored how a leader rises above the others, underlining the fact that each leader's authority defines himself and the world around. In many of Vargas Llosa's novels, the characters use words to either exercise or resist power. Their orders reflect the whims or desires of the leader, as long as he thinks he is maintaining the natural order. Vargas Llosa's work is profoundly political since it addresses an essential experience of societies, that of government ruled by a leader; it is also profoundly social since it explores the different forms of human co-existence. This Peruvian writer's works explore social and political power and in both cases, the vulnerability of the leader makes power a complex phenomenon. [Article copies available for a fee from The Transformative Studies Institute. E-mail address: journal@transformativestudies.org Website: $\quad$ http://www.transformativestudies.org (C2019 by The Transformative Studies Institute. All rights reserved.]

KEYWORDS: Latin American Fiction, Power, Violence, Leader, Authority, Politics.

\section{THE NATURE OF POWER}

The novels and stories of Vargas Llosa nearly always feature a character who plays the leader and whose iron-fisted control over the group is essential to that role. One cannot imagine a Vargas Llosa universe without a natural leader. The leader is the author himself and the collective's fate. The leader controls and defines reality; he creates a

\footnotetext{
${ }^{1}$ Alonso Cueto, Ph.D. Biography available at end of article. Address correspondence to: Alonso Cueto; e-mail: alcue6@gmail.com.
} 